\title{
Mortality with musculoskeletal disorders as underlying cause in Sweden 1997-2013: a time trend aggregate level study
}

\author{
Aliasghar A. Kiadaliri ${ }^{1,2,4^{*}}$ and Martin Englund ${ }^{1,3}$
}

\begin{abstract}
Background: The aim was to assess time trend of mortality with musculoskeletal disorders (MSD) as underlying cause of death in Sweden from 1997 to 2013.

Methods: We obtained data on MSD as underlying cause of death across age and sex groups from the National Board of Health and Welfare's Cause of Death Register. Age-standardized mortality rates per million population for all MSD, its six major subgroups, and all other ICD-10 (International Classification of Disease) chapters were calculated. We computed the average annual percent change (AAPC) in the mortality rates across age/sex groups using joinpoint regression analysis by fitting a regression line to the natural logarithm of the age-standardized mortality rates and calendar year as a predictor.

Results: There were a total of 7976 deaths ( $0.5 \%$ of all causes deaths) with MSD as the underlying cause of death (32.5\% of these deaths caused by rheumatoid arthritis [RA]). The overall age-standardized mortality rates (95\% Cl) were 16.0 (15.4 to 16.7) and 24.9 (24.1 to 25.7) per million among men and women, respectively (women/men rate ratio $1.55 ; 95 \% \mathrm{Cl} 1.47$ to 1.63 ). On average, mortality rate declined by $2.3 \%$ per year and only circulatory system mortality had a more favourable decline than mortality with MSD as underlying cause. Among MSD the highest decline was observed in RA (3.7\% per year) during study period. Across age groups, while there were generally stable or declining trends, spondylopathies and osteoporosis mortality among people $\geq 75$ years increased by 2 and $1.5 \%$ per year, respectively.

Conclusion: In overall, mortality with MSD as underlying cause has declined in Sweden over last two decades, with the highest decline for RA. However, there are variations across MSD subgroups which warrants further investigations.
\end{abstract}

Keywords: Mortality, Musculoskeletal disorders, Temporal trend, Sweden

\section{Background}

Musculoskeletal disorders (MSD) cover a wide range of disorders affecting joints, bones, muscles and soft tissues and are considered as the most common cause of severe long term pain and physical disability [1]. MSD are highly prevalent worldwide, and in a steadily aging population with increased prevalence of obesity and reduced physical activity, the prevalence of many of MSD

\footnotetext{
* Correspondence: aliasghar.ahmad_kiadaliri@med.lu.se

'Lund University, Faculty of Medicine, Department of Clinical Sciences Lund, Orthopaedics, Clinical Epidemiology Unit, Lund, Sweden

${ }^{2}$ Health Services Management Research Center, Institute for Futures Studies

in Health, Kerman University of Medical Sciences, Kerman, Iran

Full list of author information is available at the end of the article
}

will increase in coming years [2]. Globally, $21.3 \%$ of years lived with disability was attributed to MSD in 2010 (44.7 \% increase from 1990) [3]. MSD were considered as the fourth (third in developed countries) greatest contributor in disability-adjusted life years (DALYs) in 2010 [4].

In spite of substantial burden of MSD on individuals and societies, there is a lack of adequate recognition at the level of policy-making or priority [5]. In response to this, the Bone and Joint Decade 2000-2010 was endorsed by the United Nations and the World Health Organization [6]. While less attention had been paid to mortality associated with MSD, a growing recognition of 
MSD-related mortality has been emerged in recent years [7-9]. Recent evidence suggests that MSD including rheumatoid arthritis (RA) and osteoarthritis (OA) are associated with excess all-cause and disease-specific mortality [10-15]. In the Global Burden of Disease Study, MSD were considered as underlying cause of 153500 deaths worldwide in 2010 (about $0.3 \%$ of all causes deaths) and age-standardized mortality rate increased from 17 per million in 1990 to 23 per million in 2010 (a $37.8 \%$ increase) [16]. It should be noted that these numbers are underestimated because MDS are likely underreported on death certificates especially as underlying cause of death $[5,17]$.

Although, the accuracy of death certificates has been questioned [17-19], these are the main source of mortality data available for whole populations at often national level, and they are widely used in cause of death analyses. While a few studies have investigated time trend of a specific MSD such as RA [8, 20, 21] and systemic lupus erythematosus [22-24], updated information on mortality is needed, for instance due to the introduction of new biological drugs in the treatments of many inflammatory rheumatic diseases. Also, to our best knowledge, no previous study has investigated all mortality associated with MSD and its major subgroups in a single study using the same data source and uniform methodology. Thus, our aim was to provide an up-to-date data on the recent trend of mortality with MSD and its six subgroups as underlying cause in Sweden during 19972013. Such data not only provide tools to monitor progress towards national public health goals but also helps to evaluate interventions, to identify high risk population subgroups, and to make future projections.

\section{Methods}

\section{Data sources}

Data on population across sex and age groups were collected from the Statistics Sweden (http://www.scb.se). Data on mortality were obtained from the National Board of Health and Welfare's Cause of Death Register which includes all those who died during one calendar year and were registered in Sweden at the time of death, regardless of whether the death occurred inside or outside the country. The causes of death are coded centrally at the Statistics Sweden according to the International Classification of Diseases, the $10^{\text {th }}$ revision (ICD-10). The Cause of Death Register contains a single underlying cause of death, up to 48 additional contributory causes of death, and demographic data. For this study we used publicly available data which includes only the underlying cause of death by sex, age, region, and year (http://www.socialstyrelsen.se/statistics/statisticaldatabase/causeofdeath). MSD were identified as ICD-10 codes M00-M99. In addition, six major subcategories of MSD with higher mortality rates were identified: pyogenic arthritis (M00), RA (M05-M06), OA (M15-M19), systemic connective tissue disorders (M30-M35), spondylopathies (M45-M48), and osteoporosis (M80-M81). To compare the trend in mortality with MSD as underlying cause with trend in mortality from other diseases over the study period, we also included fifteen other ICD-10 chapters (Table 3 in Appendix). Due to very low mortality over study period, the following ICD-10 chapters were excluded: Diseases of the eye and adnexa (H00-H59); Diseases of the ear and mastoid process (H60-H95); and Pregnancy, childbirth and the puerperium (O00-O99).

\section{Statistical analysis}

Age-standardized mortality rates per 1 million population were calculated by means of direct standardization using the WHO Reference Population [25]. These agestandardized rates were calculated across age and sex groups. We also computed women to men agestandardized rate ratio and its $95 \%$ confidence interval [26]. The percent change was calculated as the difference between the average age-standardized rate of the last two years and the average rate of the first two years divided by the average rate the first two years. Time trends in age-standardized mortality rate were analyzed using joinpoint regression. This was done using the Joinpoint Regression Program version 4.2.0.2 from the Surveillance Research Program of the US National Cancer Institute (http://surveillance.cancer.gov/joinpoint). Joinpoint regression identifies points with a significant change in trend ("joinpoints") and determined linear trends between joinpoints. In the software a series of permutation tests proposed by Kim et al. [27] is applied to compute the number of joinpoints to best fit the data. For each joinpoint an annual percentage change (APC) is estimated by fitting a regression line to the natural logarithm of the age-standardized rates, using calendar year as a predictor. The average annual percent change (AAPC) as the weighted average of APCs was computed to provide a summary measure of the trend for the whole time period [28]. We used the empirical quantile method with 1000 resamples to calculate $95 \%$ confidence interval of AAPC. Since the empirical quantile method is not available for comparison between groups, we used parametric method to compare AAPC of MSD mortality with other ICD-10 chapters. In trend analysis across age groups, due to low number of death in MSD subcategories, we smoothed the mortality rates using a four-year moving average.

It has been suggested that several MSD should not be considered as underlying cause of death (defined as "garbage codes", Table 4 in Appendix) [29]. In a sensitivity analysis, we calculated the AAPC excluding deaths 
attributed to these causes. It should be noted that across the MSD subcategories, excluding these "garbage codes" only influenced OA and spondylopathies. In addition, because all OA codes (M15-M19) are considered as "garbage codes", we did our sensitivity analysis only on all MSD and spondylopathies.

\section{Results}

During 1997 to 2013, 2411 men and 5565 women had a MSD registered as their underlying cause of death in Sweden $(0.3$ and $0.7 \%$ of all causes mortality among men and women, Table 5 in Appendix). In overall, among MSD, RA was the leading cause of death $(32.5 \%$ all deaths) followed by systemic connective tissue disorders (23.4 \% of all deaths). Across age and sex groups, while RA was the leading cause of death for men and women aged 65 years and older, among younger people systemic connective tissue disorders were associated with the highest number of deaths (45.9\% of all death in this age group, Fig. 1).

The overall age-standardized mortality rates (95\% CI) were 16.0 (15.4 to 16.7) and 24.9 (24.1 to 25.7) per million among men and women, respectively. This figures corresponded to a statistically significant women/ men rate ratio (95\% CI) of 1.55 (1.47 to 1.63). Across MSD subcategories, while women had statistically significantly a higher age-standardized mortality rate for RA, systemic connective tissue disorders, and osteoporosis as underlying cause compared to men, opposite was observed for pyogenic arthritis and spondylopathies (Table 1).

The age-standardized mortality rate of MSD as underlying cause for Swedish population declined from 24.7 per million in 1997 to 17.2 per million in 2013 (a percent change of $-27.8 \%$, Fig. 2a). While women had higher mortality rates than men in all study years, the disparity was declining over time. Across age groups, while age-standardized rate substantially declined in 2013 compared to 1997 among younger age groups (the percent change of -42.2 and $-45.0 \%$ in $0-64$ and $65-74$ years groups, respectively), a smaller decline of $9.7 \%$ was observed among oldest age group (from 365.3 per million in 1997 to 342.3 per million in 2013, Fig. 2b).

On average, the age-standardized mortality rate declined by $2.3 \%$ (95 \% CI: 1.5 to 3.1 ) annually during the study period in Sweden (Fig. 3). Among MSD subcategories while there were statistically significant declining trend for RA, OA, systemic connective tissue disorders, and spondylopathies, the trends for pyogenic arthritis and osteoporosis were stable during 1997-2013. Among ICD-10 chapters, only diseases of the circulatory system (I00-I99) had a more profound reduction than MSD (Table 2). There was no statistically significant difference in AAPC of MSD and four other chapters (i.e., diseases of the respiratory system (J00-J99), diseases of the genitourinary system (N00-N99), certain conditions originating in the perinatal period (P00-P96), and congenital malformations, deformations and chromosomal abnormalities (Q00-Q99)).

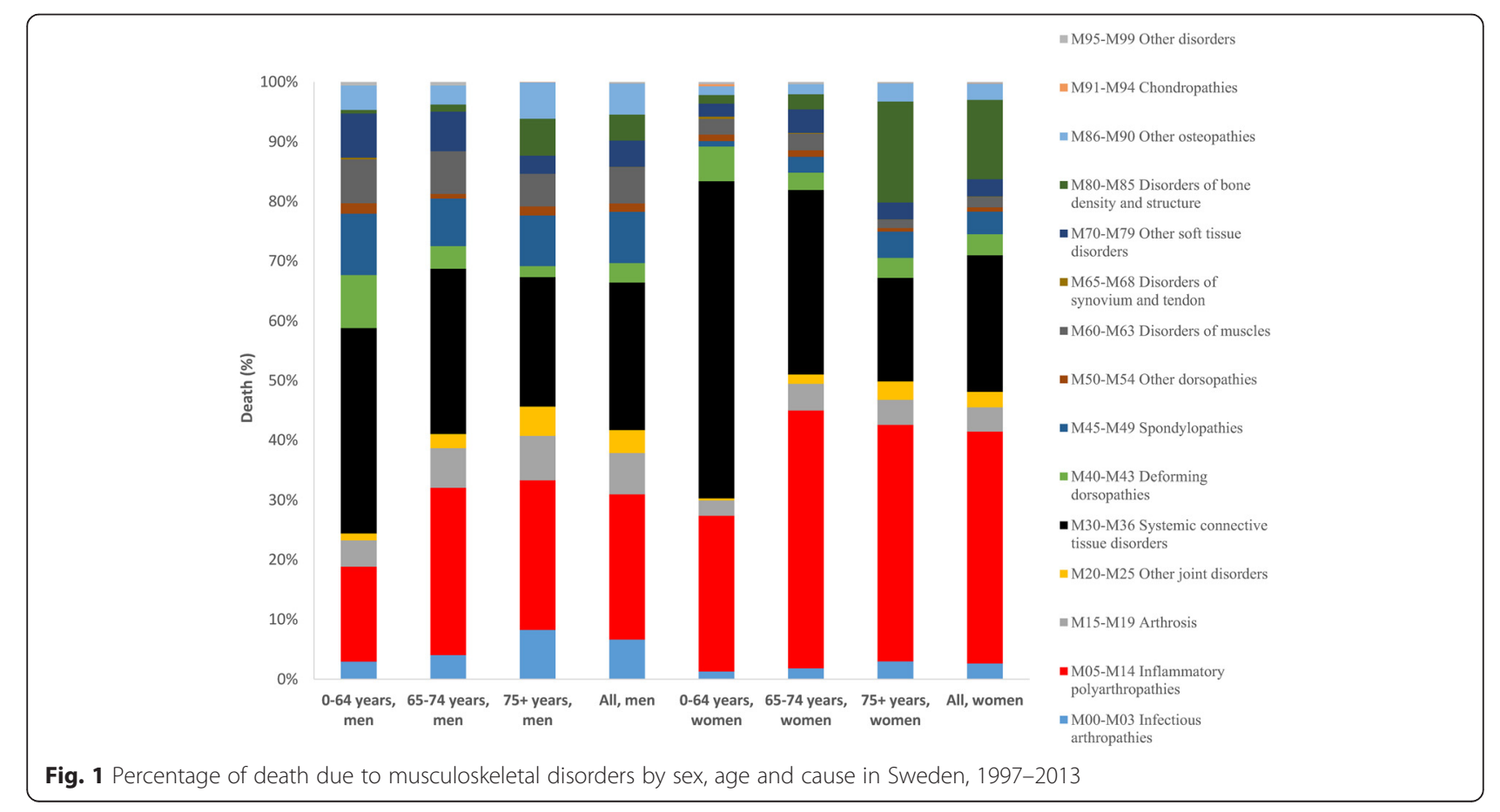


Table 1 Overall age-standardized mortality rate of musculoskeletal disorders as underlying cause per million people in Sweden, 1997-2013

\begin{tabular}{|c|c|c|c|}
\hline ICD title (codes) & Women & Men & Women/men rate ratic \\
\hline All musculoskeletal disorders (M00-M99) & 24.9 (24.1 to 25.7$)$ & $16.0(15.4$ to 16.7$)$ & $1.6(1.5$ to 1.6$)$ \\
\hline Pyogenic arthritis (M00) & 0.56 (0.46 to 0.67$)$ & 0.94 (0.79 to 1.09$)$ & $0.60(0.47$ to 0.76$)$ \\
\hline Rheumatoid arthritis (M05-M06) & $8.9(8.5$ to 9.4$)$ & 3.4 (3.2 to 3.7$)$ & $2.6(2.4$ to 2.9$)$ \\
\hline Osteoarthritis (M15-M19) & $0.94(0.80$ to 1.1$)$ & $1.0(0.88$ to 1.2$)$ & 0.90 (0.73 to 1.1$)$ \\
\hline Systemic connective tissue disorders (M30-M35) & $7.3(6.8$ to 7.7$)$ & 4.2 (3.9 to 4.6$)$ & $1.7(1.6$ to 1.9$)$ \\
\hline Spondylopathies (M45-M48) & 0.75 (0.64 to 0.87$)$ & $1.4(1.2$ to 1.6$)$ & 0.55 (0.45 to 0.67$)$ \\
\hline Osteoporosis (M80-M81) & 2.1 (1.9 to 2.2 ) & 0.45 (0.35 to 0.54$)$ & 4.7 (3.7 to 5.9$)$ \\
\hline
\end{tabular}

Our subgroup analyses across age and sex groups revealed that among men and women the highest decline was observed in RA (3.2\% per year) and OA ( $4.9 \%$ per year), respectively. While women experienced a statistically significant decline in mortality with systemic connective tissue disorders as underlying cause, this was relatively constant among men $(\mathrm{AAPC}=-2.0 \%, P=$ $0.20)$. Across age groups, the oldest age group (75+ years) experienced less profound changes in mortality with MSD as underlying cause (Fig. 4). While people aged 0-64 experienced a statistically significant decline in mortality with pyogenic arthritis as underlying cause, the trend was constant among older people. On the other hand, the trend in mortality with OA as underlying cause was constant among people aged 0-64 years and declining among older age groups. In addition, while mortality with spondylopathies and osteoporosis as underlying cause were either declining or constant among younger age groups (i.e., $0-64$, and 65-74 years), these have increased among the oldest age group during the study period. Of course, mortality rate of osteoporosis as underlying cause steadily declined by $1.2 \%$ per year since 2001 but a sharp increase of $10.9 \%$ per year during 1997-2001 resulted in an overall increasing trend for this subgroup.

A total of 1543 (19.3\%) of deaths with MSD as underlying cause were attributed to garbage codes (25.7 and $16.6 \%$ of deaths among men and women, respectively, Table 5 in Appendix). Excluding these potential garbage codes had negligible impact on AAPC of mortality with MSD as underlying cause among women and in total population (among women AAPC changed from

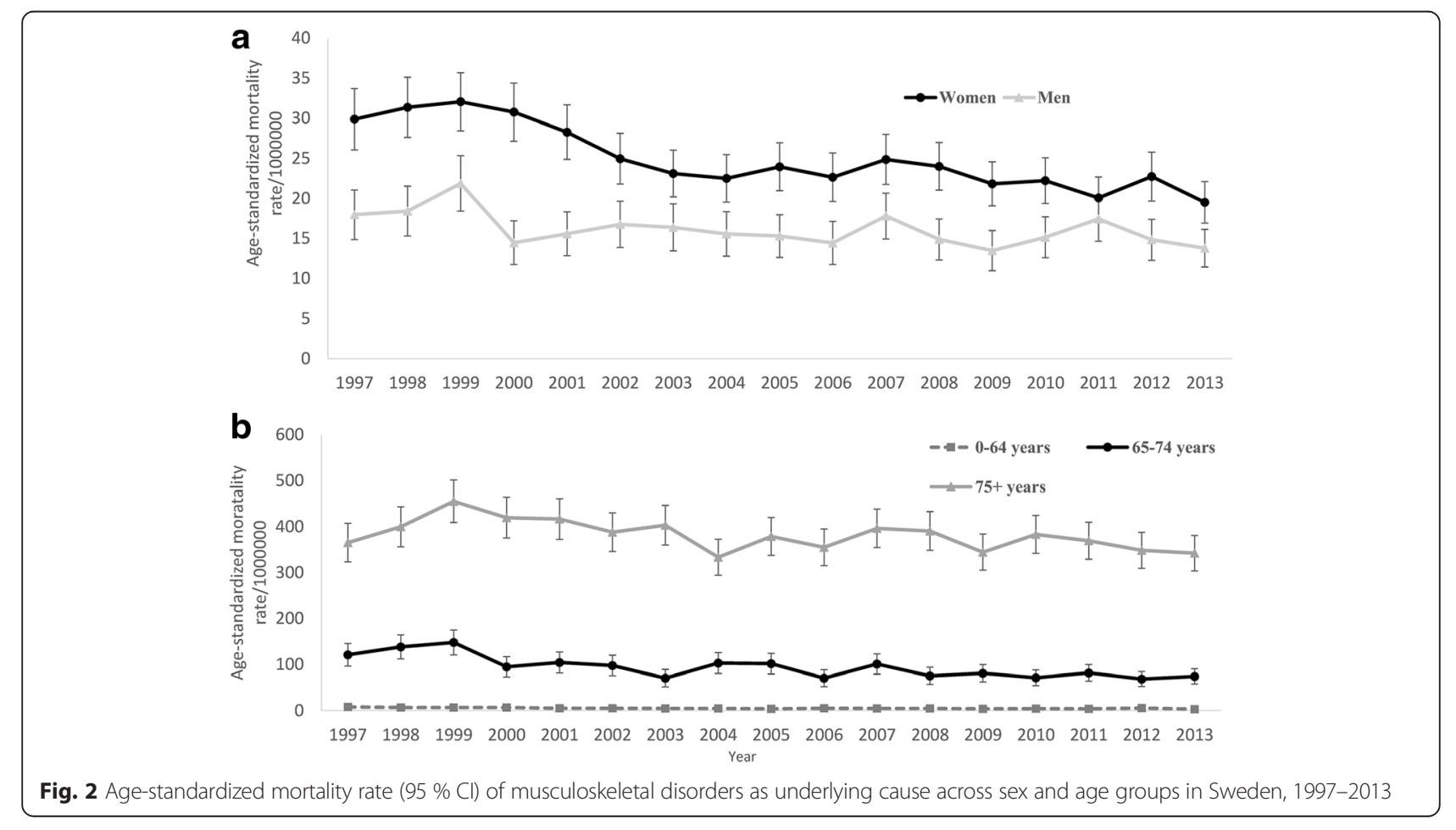




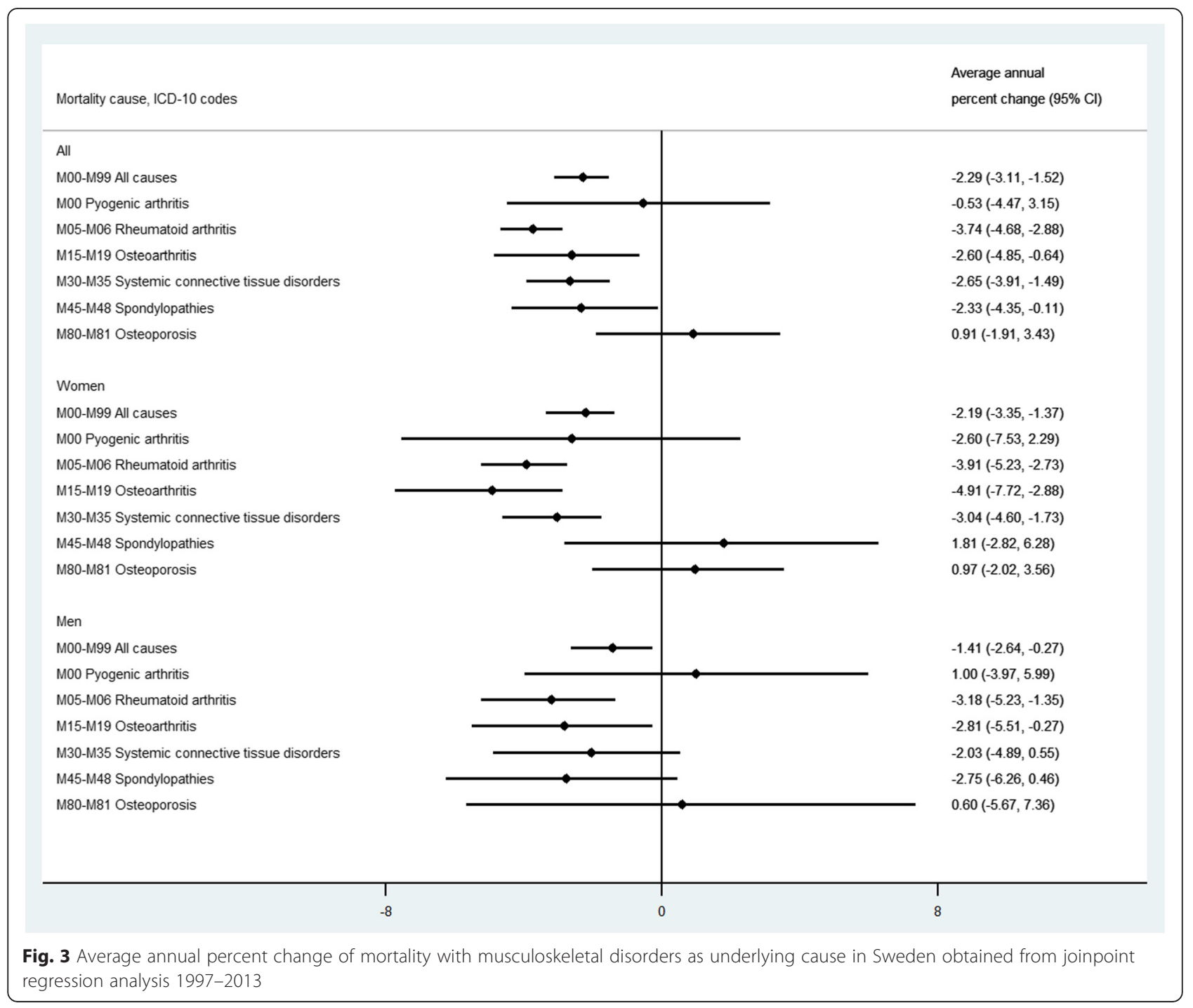

-2.2 to $-2.7 \%$ and in total population from -2.3 to $-2.1 \%)$. However, excluding these garbage codes resulted in a statistically non-significant AAPC of $-0.9 \%$ $(P=0.21)$ among men. In addition, across age groups, the declining trend for mortality with MSD as underlying cause among people aged $\geq 75$ years was no longer statistically significant (AAPC $=-0.5 \%, P=0.45$ ). For mortality with spondylopathies as underlying cause, the exclusion of garbage codes only influenced the trend for the total population and it became no longer statistically significant $(\mathrm{AAPC}=-0.3 \%, P=0.88$ ).

\section{Discussion}

In the current study, we have presented an up-to-date data on recent trends in mortality with MSD and its six major subcategories as underlying cause in Sweden. Our results showed that MSD were recorded as underlying cause of death on $0.5 \%$ of all death certificates during
1997-2013. We found evidence that mortality with MSD as underlying cause declined during the study period and its annual decline was generally more profound than for other disease categories. Although the age-standardized mortality rates of MSD as underlying cause declined in both men and women, our subgroup analyses revealed important variations in MSD subcategories across age and sex groups. In addition, while women had higher mortality rates compared with men, this gender disparity was declining over time.

Comparing the recent (2007-2013) mortality with MSD as underlying cause in Sweden with Denmark (http://www.statbank.dk/), Australia (http://www.aihw.gov.au/deaths/grim-books/) and USA (http://wonder.cdc.gov/ucd-icd10.html) showed that while the proportion of MSD from all-cause mortality was similar across countries $(0.5 \%$ in Sweden, $0.6 \%$ in USA, and $0.8 \%$ in Denmark and Australia), Sweden had the lowest age- 
Table 2 Annual percent change and average annual percent change in age-standardized mortality rates for ICD-10 chapters, 1997-2013

\begin{tabular}{|c|c|c|c|c|c|c|}
\hline \multirow[t]{2}{*}{ ICD-10 chapter (codes) } & \multicolumn{2}{|c|}{$\begin{array}{l}\text { Age-standardized mortality } \\
\text { rate per million people }\end{array}$} & \multirow[t]{2}{*}{ Period } & \multirow[t]{2}{*}{ APC, \% } & \multirow[t]{2}{*}{ AAPC, \% } & \multirow{2}{*}{$\begin{array}{l}\text { Mean difference }(95 \% \mathrm{Cl} \text { ) } \\
\text { in AAPC compared with } \\
\text { MSD (M00-M99) }\end{array}$} \\
\hline & 1997 & 2013 & & & & \\
\hline Certain infectious and parasitic diseases (A00-B99) & 45.2 & 85.3 & $1997-2013$ & $4.25^{* * *}$ & $4.25^{* * *}$ & 6.54 (5.71 to 7.37$)$ \\
\hline \multirow[t]{3}{*}{ Neoplasms (C00-D48) } & \multirow[t]{3}{*}{1270.7} & \multirow[t]{3}{*}{1084.9} & 1997-2005 & $-0.57^{* * *}$ & \multirow[t]{3}{*}{$-0.92^{* * *}$} & \multirow[t]{3}{*}{1.34 (0.72 to 2.03$)$} \\
\hline & & & $2005-2010$ & $-1.73^{* * *}$ & & \\
\hline & & & 2010-2013 & -0.49 & & \\
\hline $\begin{array}{l}\text { Diseases of the blood and blood-forming organs } \\
\text { and certain disorders involving the immune } \\
\text { mechanism (D50-D89) }\end{array}$ & 10.0 & 11.3 & $1997-2013$ & 0.61 & 0.61 & 2.90 (1.88 to 3.91$)$ \\
\hline \multirow[t]{2}{*}{ Endocrine, nutritional and metabolic diseases (E00-E90) } & \multirow[t]{2}{*}{104.4} & \multirow[t]{2}{*}{102.6} & 1997-2005 & 0.97 & \multirow[t]{2}{*}{-0.15} & \multirow[t]{2}{*}{2.15 (1.22 to 3.07$)$} \\
\hline & & & 2005-2013 & $-1.24^{*}$ & & \\
\hline \multirow[t]{3}{*}{ Mental and behavioural disorders (F00-F99) } & \multirow[t]{3}{*}{141.7} & \multirow[t]{3}{*}{184.4} & 1997-1999 & 11.54 & \multirow[t]{3}{*}{1.67} & \multirow[t]{3}{*}{3.97 (1.87 to 6.06$)$} \\
\hline & & & 1999-2010 & -0.61 & & \\
\hline & & & 2010-2013 & 3.89 & & \\
\hline Diseases of the nervous system (G00-G99) & 99.9 & 159.6 & 1997-2013 & $3.39^{* * *}$ & $3.39 * * *$ & 5.69 (4.93 to 6.44$)$ \\
\hline \multirow[t]{3}{*}{ Diseases of the circulatory system (100-199) } & \multirow[t]{3}{*}{2038.4} & \multirow[t]{3}{*}{1202.0} & $1997-2002$ & $-2.83^{* * *}$ & \multirow[t]{3}{*}{$-3.27^{* * *}$} & \multirow[t]{3}{*}{$-0.98(-1.76$ to -0.20$)$} \\
\hline & & & 2002-2005 & $-4.55^{* *}$ & & \\
\hline & & & $2005-2013$ & $-3.07^{* * *}$ & & \\
\hline \multirow[t]{2}{*}{ Diseases of the respiratory system (J00-J99) } & \multirow[t]{2}{*}{303.4} & \multirow[t]{2}{*}{227.9} & 1997-2010 & $-2.71^{* * *}$ & \multirow[t]{2}{*}{$-1.65^{* *}$} & $0.64(-0.69$ to 1.98$)$ \\
\hline & & & 2010-2013 & 3.06 & & \\
\hline Diseases of the digestive system (K00-K93) & 141.7 & 120.3 & 1997-2006 & -0.01 & $-1.30^{* *}$ & 0.99 (0.01 to 1.98$)$ \\
\hline & & & $2006-2013$ & $-2.92^{* *}$ & & \\
\hline Diseases of the skin and subcutaneous tissue (L00-L99) & 7.0 & 6.3 & 1997-2013 & -0.53 & -0.53 & 1.76 (0.58 to 2.94$)$ \\
\hline $\begin{array}{l}\text { Diseases of the musculoskeletal system and connective } \\
\text { tissue (M00-M99) }\end{array}$ & 24.7 & 17.2 & 1997-2013 & $-2.29^{* * *}$ & $-2.29^{* * *}$ & - \\
\hline Diseases of the genitourinary system (N00-N99) & 54.2 & 38.5 & $1997-2013$ & $-2.80^{* * *}$ & $-2.80^{* * *}$ & $-0.51(-1.37$ to 0.36$)$ \\
\hline Certain conditions originating in the perinatal & 23.1 & 21.9 & 1997-2003 & $5.40^{*}$ & -0.58 & $1.71(-3.28$ to 6.70$)$ \\
\hline period (P00-P96) & & & 2003-2006 & -14.93 & & \\
\hline & & & $2006-2013$ & 1.09 & & \\
\hline $\begin{array}{l}\text { Congenital malformations, deformations and } \\
\text { chromosomal abnormalities (Q00-Q99) }\end{array}$ & 36.5 & 25.4 & 1997-2013 & $-3.14^{* * *}$ & $-3.14^{* * *}$ & $-0.85(-1.82$ to 0.13$)$ \\
\hline Symptoms, signs and abnormal clinical and & 95.7 & 123.2 & 1997-2007 & 1.09 & 0.85 & 3.14 (0.05 to 6.23$)$ \\
\hline & & & $2007-2010$ & 13.79 & & \\
\hline & & & 2010-2013 & $-11.30^{* *}$ & & \\
\hline External causes of morbidity and mortality (V01-Y98) & 338.6 & 309.3 & $1997-2013$ & $-0.78^{*}$ & $-0.78^{*}$ & 1.51 (0.71 to 2.31$)$ \\
\hline
\end{tabular}

*** $P<0.001 ; * * P<0.01 ; * P<0.05$

$A P C$ annual percent change, $A A P C$ average annual percent change, MSD musculoskeletal disorders

standardized mortality rate (pooled age-standardized mortality rate per million people: Sweden 21.1, USA 26.3, Denmark 32.9, and Australia 26.4). The differences in sociodemographic status, health care system, and mortality coding practices might be potential reasons for observed difference in mortality rates across these countries.

We found that mortality with MSD its four subcategories (i.e. RA, OA, systemic connective tissue disorders, and spondylopathies) as underlying cause statistically significantly declined in Sweden over the study period. This finding is in line with declining trend in mortality from RA, systemic lupus erythematosus, ankylosing spondylitis and polyarteritis nodosa in France [8], Spain [24], and England [30]. Better management of MSD induced by advancement in pharmacological interventions and medical procedures might explain this observed declining trend. For example, a recent study showed that time 


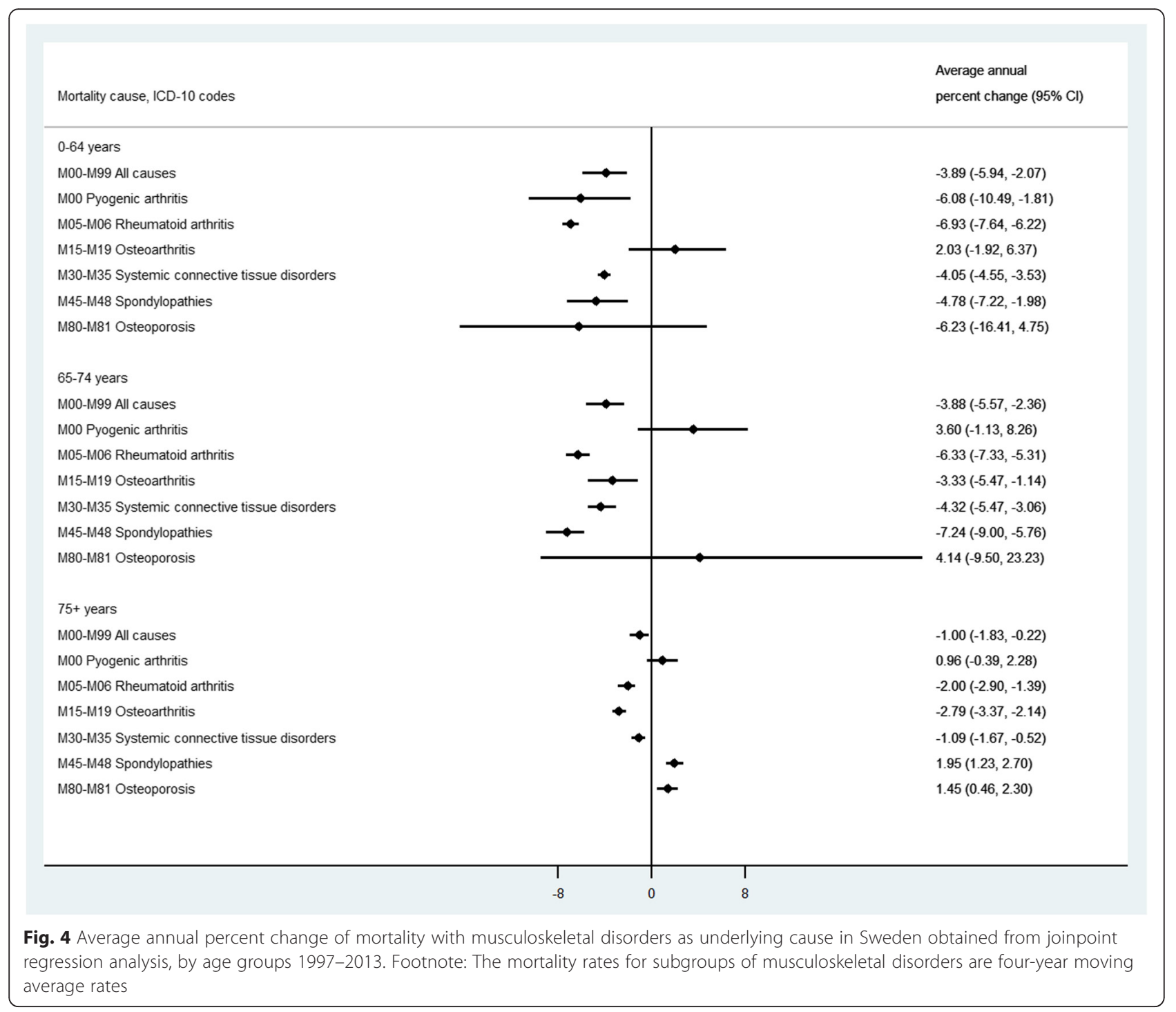

to initiation disease modifying antirheumatic drug has substantially shortened over the past four decades among people with RA [31]. Nevertheless, analysis across age groups revealed an increase in mortality with spondylopathies and osteoporosis as underlying cause among the oldest (aged $\geq 75$ years). This might be due to aging population which has increased number of older people. Moreover, promoted awareness of the severity of these conditions in recent years might have increased reporting them as a cause of death [32]. Further research is required to explain these increasing trends among the most elderly.

The mortality rates of MSD and its three subcategories (i.e., RA, systemic connective tissue disorders, and osteoporosis) as underlying cause were higher among women compared to men and this is mainly attributed to higher prevalence of these disorders among women [33, 34].
Previous studies have suggested similar gender inequality for RA $[8,20,21]$, dermatomyositis and polymyositis [35], and systemic lupus erythematosus [22, 24]. On the other hand, men had higher mortality rates of pyogenic arthritis and spondylopathies as underlying cause compared with women. The similar pattern for ankylosing spondylitis was observed in England [30]. This might be due to higher prevalence of these disorders among men and also difference in severity of disease. For example, previous studies reported a higher prevalence of ankylosing spondylitis, lumbar spondylosis, and cervical spondylosis among men [36-38] and a tendency to have more severe ankylosing spondylitis compared with women [39]. While, these gender gaps were generally closing over time, more efforts are required for further reduction. For example, if we naively assume that the projected trends in mortality with MSD as underlying 
cause will be observed during next 10 years, then AAPC for women should be doubled during this period (i.e., increase from -2.2 to $-4.7 \%$ ) in order to close observed gender gap in our study.

The limitations of the current study should also be considered when interpreting its findings. We only analyzed mortality due to underlying cause of death which suffers from underestimation for MSD as these are not usually considered as underlying cause of death [5]. Inaccuracy and errors in completion of death certificate are another potential limitation of our study, but is unlikely to have substantially changed over time [18]. The small number of deaths, especially for MSD subgroups, might have limited the power of our study to detect significant joinpoints during the study period. In addition, because our study was an ecological study with no individual-level data available, we were unable to adjust for any potential confounders in addition to age and sex. Also, we cannot further examine factors influencing the observed trend in mortality with MSD as underlying cause. In spite of these limitations, the current study have important implications including new insight about recent temporal trends in mortality with MSD as underlying cause of death which might be used to predict mortality rates in coming years in Sweden. The findings can be used to develop a hypothesis that increased use of biological treatments in e.g. RA has impacted on mortality associated with MSD. In addition, the observed increasing trends in mortality with spondylopathies and osteoporosis as underlying cause require further attention.

\section{Conclusion}

The mean age-standardized mortality rate with MSD as underlying cause was 21.1 per million people per year in Sweden during 1997-2013. The present study indicated that mortality with MSD as underlying cause declined by $2.3 \%$ per year in Sweden and this reduction was generally more favourable than other ICD-10 chapters. However, we found variations in time trends for MSD subcategories across sex and age groups. Our findings revealed that older people (aged $\geq 75$ years) observed an increasing trend in mortality with spondylopathies and osteoporosis as underlying cause which warrants further investigations. Moreover, while mortality rates of MSD and its three subcategories (RA, systemic connective tissue disorders, and osteoporosis) as underlying cause were higher among women, more Swedish men died from pyogenic arthritis and spondylopathies during the study period. Analyzing time trend in MSD mortality using multiple cause of death framework and using individual-level data are subjects for future studies.

\section{Availability of supporting data}

All relevant raw data are freely available from the Swedish Cause of Death Register (http://www.socialstyrelsen.se/ statistics/statisticaldatabase/causeofdeath).

\section{Ethics approval and consent to participate}

Not applicable (publicly available data were used).

\section{Appendix}

Table 3 The ICD-10 chapters included in the study for comparison

\begin{tabular}{ll}
\hline ICD-10 title & ICD codes \\
\hline Certain infectious and parasitic diseases & A00-B99 \\
Neoplasms & C00-D48 \\
Diseases of the blood and blood-forming organs and certain disorders involving the immune mechanism & D50-D89 \\
Endocrine, nutritional and metabolic diseases & E00-E90 \\
Mental and behavioural disorders & F00-F99 \\
Diseases of the nervous system & G00-G99 \\
Diseases of the circulatory system & I00-199 \\
Diseases of the respiratory system & J00-J99 \\
Diseases of the digestive system & K00-K93 \\
Diseases of the skin and subcutaneous tissue & L00-L99 \\
Diseases of the genitourinary system & N00-N99 \\
Certain conditions originating in the perinatal period & P00-P96 \\
Congenital malformations, deformations and chromosomal abnormalities & Q00-Q99 \\
Symptoms, signs and abnormal clinical and laboratory findings, not elsewhere classified & R00-R99 \\
External causes of morbidity and mortality & V01-Y98 \\
\hline
\end{tabular}


Table 4 Musculoskeletal disorders considered as garbage codes and excluded in a sensitivity analysis

\begin{tabular}{|c|c|c|c|}
\hline \multirow[t]{2}{*}{ ICD-10 title } & \multirow[t]{2}{*}{ ICD codes } & \multicolumn{2}{|c|}{ Total number of deaths 1997-2013 } \\
\hline & & Men & Women \\
\hline Postinfective and reactive arthropathies in diseases classified elsewhere & M03 & 0 & 0 \\
\hline Psoriatic and enteropathic arthropathies & M07 & 0 & 0 \\
\hline Juvenile arthritis in diseases classified elsewhere & M09 & 0 & 0 \\
\hline Gout & M10 & 19 & 28 \\
\hline Other crystal arthropathies & M11 & 2 & 3 \\
\hline Other specific arthropathies & M12 & 0 & 0 \\
\hline Arthropathies in other diseases classified elsewhere & M14 & 0 & 0 \\
\hline Osteoarthritis & M15-M19 & 165 & 227 \\
\hline Other joint disorders & M20-M25 & 93 & 145 \\
\hline Kyphosis and lordosis & M40 & 14 & 52 \\
\hline Spondylosis & M47 & 9 & 5 \\
\hline Other spondylopathies & M48 & 81 & 154 \\
\hline Spondylopathies in diseases classified elsewhere & M49 & 0 & 0 \\
\hline Cervical disc disorders & M50 & 5 & 6 \\
\hline Other intervertebral disc disorders & M51 & 10 & 6 \\
\hline Other dorsopathies, not elsewhere classified & M53 & 4 & 5 \\
\hline Dorsalgia & M54 & 15 & 23 \\
\hline Myositis & M60 & 45 & 27 \\
\hline Disorders of muscle in diseases classified elsewhere & M63 & 0 & 0 \\
\hline Disorders of synovium and tendon & M65-M68 & 1 & 4 \\
\hline Soft tissue disorders related to use, overuse and pressure & M70 & 11 & 7 \\
\hline Other bursopathies & M71 & 9 & 2 \\
\hline Soft tissue disorders in diseases classified elsewhere & M73 & 0 & 0 \\
\hline Shoulder lesions & M75 & 0 & 0 \\
\hline Enthesopathies of lower limb, excluding foot & M76 & 0 & 0 \\
\hline Other enthesopathies & M77 & 0 & 0 \\
\hline Other soft tissue disorders, not elsewhere classified & M79 & 27 & 105 \\
\hline Osteomyelitis & M86 & 104 & 112 \\
\hline Other disorders of the musculoskeletal system and connective tissue & M95-M99 & 5 & 13 \\
\hline
\end{tabular}

Table 5 Number of death across musculoskeletal disorders subgroups by sex and year

\begin{tabular}{|c|c|c|c|c|c|c|c|c|c|c|c|c|c|c|c|c|c|c|}
\hline ICD-10 title (codes) & & 1997 & 1998 & 1999 & 2000 & 2001 & 2002 & 2003 & 2004 & 2005 & 2006 & 2007 & 2008 & 2009 & 2010 & 2011 & 2012 & 2013 \\
\hline \multirow{2}{*}{$\begin{array}{l}\text { Infectious arthropathies } \\
\text { (M00-M03) }\end{array}$} & Men & 13 & 6 & 9 & 4 & 6 & 10 & 11 & 4 & 13 & 5 & 10 & 5 & 9 & 15 & 11 & 13 & 15 \\
\hline & Women & 9 & 6 & 15 & 15 & 7 & 6 & 5 & 8 & 8 & 9 & 3 & 12 & 7 & 11 & 13 & 6 & 7 \\
\hline \multirow{2}{*}{$\begin{array}{l}\text { Inflammatory polyarthropathies } \\
\text { (M05-M14) }\end{array}$} & Men & 41 & 35 & 37 & 27 & 41 & 37 & 44 & 37 & 33 & 34 & 41 & 26 & 26 & 24 & 37 & 32 & 36 \\
\hline & Women & 127 & 137 & 159 & 151 & 161 & 118 & 133 & 108 & 128 & 131 & 126 & 125 & 134 & 107 & 110 & 113 & 90 \\
\hline \multirow[t]{2}{*}{ Osteoarthritis (M15-M19) } & Men & 6 & 12 & 13 & 13 & 8 & 11 & 10 & 11 & 9 & 12 & 8 & 6 & 10 & 10 & 9 & 8 & 9 \\
\hline & Women & 18 & 16 & 16 & 13 & 13 & 13 & 8 & 12 & 13 & 14 & 13 & 14 & 15 & 8 & 16 & 13 & 12 \\
\hline \multirow{2}{*}{$\begin{array}{l}\text { Other joint disorders } \\
(\mathrm{M} 20-\mathrm{M} 25)\end{array}$} & Men & 14 & 18 & 13 & 9 & 3 & 2 & 0 & 4 & 2 & 3 & 0 & 2 & 3 & 6 & 4 & 5 & 5 \\
\hline & Women & 15 & 29 & 30 & 11 & 8 & 5 & 4 & 4 & 6 & 2 & 5 & 2 & 1 & 6 & 4 & 5 & 8 \\
\hline \multirow{2}{*}{$\begin{array}{l}\text { Systemic connective tissue } \\
\text { disorders (M30-M36) }\end{array}$} & Men & 34 & 40 & 43 & 31 & 29 & 42 & 38 & 28 & 33 & 28 & 37 & 43 & 30 & 41 & 45 & 24 & 30 \\
\hline & Women & 79 & 81 & 91 & 90 & 82 & 73 & 73 & 79 & 74 & 65 & 72 & 79 & 71 & 65 & 63 & 70 & 65 \\
\hline \multirow{2}{*}{$\begin{array}{l}\text { M40-M43 Deforming } \\
\text { dorsopathies (M40-M43) }\end{array}$} & Men & 2 & 2 & 3 & 4 & 2 & 4 & 4 & 8 & 5 & 8 & 10 & 1 & 6 & 5 & 2 & 7 & 5 \\
\hline & Women & 5 & 11 & 9 & 10 & 11 & 17 & 13 & 10 & 6 & 13 & 14 & 16 & 13 & 17 & 13 & 9 & 10 \\
\hline
\end{tabular}


Table 5 Number of death across musculoskeletal disorders subgroups by sex and year (Continued)

\begin{tabular}{|c|c|c|c|c|c|c|c|c|c|c|c|c|c|c|c|c|c|c|}
\hline \multirow{2}{*}{$\begin{array}{l}\text { Spondylopathies } \\
\text { (M45-M49) }\end{array}$} & Men & 18 & 15 & 11 & 10 & 13 & 7 & 10 & 18 & 11 & 8 & 12 & 15 & 11 & 8 & 10 & 20 & 11 \\
\hline & Women & 9 & 11 & 18 & 11 & 6 & 15 & 9 & 7 & 11 & 8 & 11 & 11 & 12 & 17 & 21 & 13 & 21 \\
\hline \multirow{2}{*}{$\begin{array}{l}\text { Other dorsopathies } \\
\text { (M50-M54) }\end{array}$} & Men & 1 & 1 & 3 & 1 & 5 & 0 & 3 & 3 & 3 & 0 & 3 & 3 & 3 & 3 & 0 & 1 & 1 \\
\hline & Women & 3 & 1 & 9 & 0 & 3 & 2 & 1 & 3 & 5 & 0 & 3 & 2 & 2 & 1 & 2 & 2 & 1 \\
\hline \multirow{2}{*}{$\begin{array}{l}\text { Disorders of muscles } \\
\text { (M60-M63) }\end{array}$} & Men & 0 & 4 & 10 & 4 & 3 & 8 & 6 & 4 & 8 & 11 & 15 & 14 & 11 & 16 & 17 & 11 & 5 \\
\hline & Women & 2 & 1 & 4 & 9 & 3 & 4 & 6 & 2 & 6 & 7 & 9 & 3 & 6 & 8 & 11 & 7 & 9 \\
\hline \multirow{2}{*}{$\begin{array}{l}\text { Disorders of synovium and } \\
\text { tendon (M65-M68) }\end{array}$} & Men & 0 & 0 & 0 & 0 & 1 & 0 & 0 & 0 & 0 & 0 & 0 & 0 & 0 & 0 & 0 & 0 & 0 \\
\hline & Women & 1 & 0 & 0 & 0 & 0 & 0 & 1 & 1 & 1 & 0 & 0 & 0 & 0 & 0 & 0 & 0 & 0 \\
\hline \multirow{2}{*}{$\begin{array}{l}\text { Other soft tissue disorders } \\
\text { (M70-M79) }\end{array}$} & Men & 2 & 7 & 12 & 2 & 10 & 8 & 3 & 3 & 5 & 4 & 9 & 9 & 4 & 2 & 7 & 9 & 10 \\
\hline & Women & 16 & 16 & 4 & 12 & 6 & 8 & 11 & 10 & 9 & 4 & 18 & 11 & 8 & 8 & 7 & 8 & 7 \\
\hline \multirow{2}{*}{$\begin{array}{l}\text { Disorders of bone density } \\
\text { and structure (M80-M85) }\end{array}$} & Men & 1 & 2 & 5 & 7 & 6 & 6 & 4 & 3 & 11 & 5 & 11 & 11 & 6 & 7 & 8 & 5 & 6 \\
\hline & Women & 29 & 31 & 34 & 37 & 43 & 54 & 45 & 32 & 48 & 45 & 53 & 50 & 38 & 58 & 30 & 53 & 57 \\
\hline \multirow{2}{*}{$\begin{array}{l}\text { Other osteopathies } \\
\text { (M86-M90) }\end{array}$} & Men & 7 & 5 & 11 & 5 & 4 & 5 & 3 & 7 & 4 & 8 & 8 & 6 & 3 & 12 & 20 & 9 & 9 \\
\hline & Women & 10 & 16 & 3 & 10 & 11 & 5 & 4 & 13 & 10 & 6 & 9 & 7 & 3 & 12 & 12 & 11 & 9 \\
\hline \multirow[t]{2}{*}{ Chondropathies (M91-M94) } & Men & 0 & 0 & 0 & 0 & 0 & 0 & 0 & 0 & 0 & 0 & 0 & 0 & 0 & 0 & 0 & 1 & 0 \\
\hline & Women & 0 & 1 & 0 & 0 & 0 & 0 & 0 & 0 & 0 & 1 & 0 & 0 & 0 & 1 & 0 & 0 & 0 \\
\hline \multirow{2}{*}{$\begin{array}{l}\text { Other disorders of the } \\
\text { musculoskeletal system and } \\
\text { connective tissue (M95-M99) }\end{array}$} & Men & 0 & 0 & 1 & 1 & 0 & 1 & 1 & 0 & 0 & 0 & 0 & 0 & 1 & 0 & 0 & 0 & 0 \\
\hline & Women & 0 & 1 & 1 & 2 & 0 & 3 & 0 & 0 & 0 & 0 & 0 & 1 & 3 & 1 & 0 & 0 & 1 \\
\hline \multirow{2}{*}{$\begin{array}{l}\text { Musculoskeletal disorders } \\
\text { (M00-M99) }\end{array}$} & Men & 139 & 147 & 171 & 118 & 131 & 141 & 137 & 130 & 137 & 126 & 164 & 141 & 123 & 149 & 170 & 145 & 142 \\
\hline & Women & 323 & 358 & 393 & 371 & 354 & 323 & 313 & 289 & 325 & 305 & 336 & 333 & 313 & 320 & 302 & 310 & 297 \\
\hline
\end{tabular}

\section{Abbreviations}

AAPC: average annual percent change; APC: annual percent change; Cl: confidence interval; DALYs: disability-adjusted life years; ICD-10: International Classification of Disease, the10th revision; MSD: musculoskeletal disorders; OA: osteoarthritis; RA: rheumatoid arthritis; WHO: World Health Organization.

\section{Competing interest}

The authors declare that they have no competing interest.

\section{Authors' contributions}

AAK participated in the design, analysis, and interpretation of results and drafting the manuscript. ME participated in interpretation of results, and revision of the manuscript for important intellectual content. All authors approved the final manuscript.

\section{Acknowledgement}

We would like to acknowledge the support from the Swedish Research Council, Crafoord Foundation, Greta and Johan Kocks Foundation, the Faculty of Medicine Lund University, Governmental Funding of Clinical Research within National Health Service (ALF) and Region Skåne. The funding sources had no influence on the study design, collection, analysis and interpretation of data, in the writing the manuscript, or in the decision to submit the manuscript for publication.

\section{Author details}

'Lund University, Faculty of Medicine, Department of Clinical Sciences Lund, Orthopaedics, Clinical Epidemiology Unit, Lund, Sweden. ${ }^{2}$ Health Services Management Research Center, Institute for Futures Studies in Health, Kerman University of Medical Sciences, Kerman, Iran. ${ }^{3}$ Clinical Epidemiology Research and Training Unit, Boston University School of Medicine, Boston, MA, USA. ${ }^{4}$ Clinical Epidemiology Unit, Skåne University Hospital, Klinikgatan 22, SE-221 85 Lund, Sweden.
Received: 15 December 2015 Accepted: 9 April 2016

Published online: 14 April 2016

\section{References}

1. Woolf AD, Pfleger B. Burden of major musculoskeletal conditions. Bull World Health Organ. 2003;81(9):646-56.

2. March L, Smith EU, Hoy DG, Cross MJ, Sanchez-Riera L, Blyth F, et al. Burden of disability due to musculoskeletal (MSK) disorders. Best Pract Res Clin Rheumatol. 2014;28(3):353-66.

3. Vos T, Flaxman AD, Naghavi M, Lozano R, Michaud C, Ezzati M, et al. Years lived with disability (YLDs) for 1160 sequelae of 289 diseases and injuries 1990-2010: a systematic analysis for the Global Burden of Disease Study 2010. Lancet. 2012;380(9859):2163-96.

4. Cross M, Smith E, Hoy D, Nolte S, Ackerman I, Fransen M, et al. The global burden of hip and knee osteoarthritis: estimates from the global burden of disease 2010 study. Ann Rheum Dis. 2014;73(7):1323-30.

5. Woolf AD, Vos T, March L. How to measure the impact of musculoskeletal conditions. Best Pract Res Clin Rheumatol. 2010;24(6):723-32.

6. Woolf AD. The bone and joint decade 2000-2010. Ann Rheum Dis. 2000; 59(2):81-2.

7. Myasoedova E, Davis 3rd JM, Crowson CS, Gabriel SE. Epidemiology of rheumatoid arthritis: rheumatoid arthritis and mortality. Curr Rheumatol Rep. 2010:12(5):379-85.

8. Ziade N, Jougla E, Coste J. Population-level influence of rheumatoid arthritis on mortality and recent trends: a multiple cause-of-death analysis in France, 1970-2002. J Rheumatol. 2008;35(10):1950-7.

9. Gabriel SE, Michaud K. Epidemiological studies in incidence, prevalence, mortality, and comorbidity of the rheumatic diseases. Arthritis Res Ther 2009;11(3):229.

10. Gonzalez A, Maradit Kremers H, Crowson CS, Nicola PJ, Davis 3rd JM, Therneau TM, et al. The widening mortality gap between rheumatoid arthritis patients and the general population. Arthritis Rheum. 2007:56(11):3583-7.

11. Nuesch E, Dieppe P, Reichenbach S, Williams S, Iff S, Juni P. All cause and disease specific mortality in patients with knee or hip osteoarthritis: population based cohort study. BMJ. 2011;342:d1165. 
12. Barbour KE, Lui LY, Nevitt MC, Murphy LB, Helmick CG, Theis KA, et al. Hip Osteoarthritis and the Risk of All-Cause and Disease-Specific Mortality in Older Women: A Population-Based Cohort Study. Arthritis Rheumatol. 2015; 67(7):1798-805.

13. McBeth J, Symmons DP, Silman AJ, Allison T, Webb R, Brammah T, et al. Musculoskeletal pain is associated with a long-term increased risk of cancer and cardiovascular-related mortality. Rheumatology (Oxford). 2009;48(1):74-7.

14. Jordan KP, Croft P. Mortality and cancer in patients with new musculoskeletal episodes: a cohort study. Br J Gen Pract. 2010;60(572):e105-11.

15. Widdifield J, Bernatsky S, Paterson JM, Tomlinson G, Tu K, Kuriya B, et al. Trends in Excess Mortality Among Patients With Rheumatoid Arthritis in Ontario, Canada. Arthritis Care Res (Hoboken). 2015;67(8):1047-53.

16. Lozano R, Naghavi M, Foreman K, Lim S, Shibuya K, Aboyans V, et al. Global and regional mortality from 235 causes of death for 20 age groups in 1990 and 2010: a systematic analysis for the Global Burden of Disease Study 2010. Lancet. 2012;380(9859):2095-128.

17. Laakso M, Isomaki $H$, Mutru $O$, Koota K. Death certificate and mortality in rheumatoid arthritis. Scand J Rheumatol. 1986;15(2):129-33.

18. Johansson LA, Westerling R. Comparing hospital discharge records with death certificates: can the differences be explained? J Epidemiol Community Health. 2002;56(4):301-8.

19. D'Amico M, Agozzino E, Biagino A, Simonetti A, Marinelli P. III-defined and multiple causes on death certificates-a study of misclassification in mortality statistics. Eur J Epidemiol. 1999;15(2):141-8.

20. Wicks IP, Moore J, Fleming A. Australian mortality statistics for rheumatoid arthritis 1950-81: analysis of death certificate data. Ann Rheum Dis. 1988; 47(7):563-9.

21. Coste J, Jougla E. Mortality from rheumatoid arthritis in France, 1970-1990. Int J Epidemiol. 1994;23(3):545-52.

22. Souza DC, Santo AH, Sato El. Mortality profile related to systemic lupus erythematosus: a multiple cause-of-death analysis. J Rheumatol. 2012;39(3): 496-503.

23. Thomas G, Mancini J, Jourde-Chiche N, Sarlon G, Amoura Z, Harle JR, et al. Mortality associated with systemic lupus erythematosus in France assessed by multiple-cause-of-death analysis. Arthritis Rheumatol. 2014;66(9):2503-11.

24. Ruiz E, Ramalle-Gomara E, Elena A, Quinones C, Alonso V, Posada M, et al. Trends in systemic lupus erythematosus mortality in Spain from 1981 to 2010. Lupus. 2014;23(4):431-5.

25. Ahmad O, Boschi-Pinto C, Lopez A, Murray C, Lozano R, Inoue M. Age standardization of rates: a new WHO standard. Geneva: World Health Organization; 2001.

26. Newman SC. Biostatistical Methods in Epidemiology. New York: Wiley; 2001.

27. Kim HJ, Fay MP, Feuer EJ, Midthune DN. Permutation tests for joinpoint regression with applications to cancer rates. Stat Med. 2000;19(3):335-51.

28. Clegg LX, Hankey BF, Tiwari R, Feuer EJ, Edwards BK. Estimating average annual per cent change in trend analysis. Stat Med. 2009;28(29):3670-82.

29. Naghavi M, Makela S, Foreman K, O'Brien J, Pourmalek F, Lozano R. Algorithms for enhancing public health utility of national causes-of-death data. Popul Health Metr. 2010;8:9.

30. Goldacre M, Duncan M, Cook-Mozaffari P, Davidson M, McGuiness $H$, Meddings D. Trends in mortality rates in England, 1996-2004. Oxford: Unit of Health-Care Epidemiology, Oxford University; 2006.

31. Kremers HM, Nicola P, Crowson CS, O'Fallon WM, Gabriel SE. Therapeutic strategies in rheumatoid arthritis over a 40-year period. J Rheumatol. 2004; 31(12):2366-73.

32. Ziade $\mathrm{N}$, Jougla $\mathrm{E}$, Coste J. Population-level impact of osteoporotic fractures on mortality and trends over time: a nationwide analysis of vital statistics for France, 1968-2004. Am J Epidemiol. 2010;172(8):942-51.

33. Turkiewicz A, Gerhardsson de Verdier M, Engstrom G, Nilsson PM, Mellstrom C, Lohmander LS, et al. Prevalence of knee pain and knee OA in southern Sweden and the proportion that seeks medical care. Rheumatology (Oxford). 2015;54(5):827-35.

34. Symmons D, Turner G, Webb R, Asten P, Barrett E, Lunt M, et al. The prevalence of rheumatoid arthritis in the United Kingdom: new estimates for a new century. Rheumatology (Oxford). 2002;41(7):793-800.

35. Santo AH, Souza JM, Pinheiro CE, Souza DC, Sato El. Trends in dermatomyositis- and polymyositis-related mortality in the state of Sao Paulo, Brazil, 1985-2007: multiple cause-of-death analysis. BMC Public Health. 2010;10:597.
36. Dean LE, Jones GT, MacDonald AG, Downham C, Sturrock RD, Macfarlane GJ. Global prevalence of ankylosing spondylitis. Rheumatology (Oxford). 2014;53(4):650-7.

37. Yoshimura N, Muraki S, Oka H, Mabuchi A, En-Yo Y, Yoshida M, et al. Prevalence of knee osteoarthritis, lumbar spondylosis, and osteoporosis in Japanese men and women: the research on osteoarthritis/osteoporosis against disability study. J Bone Miner Metab. 2009;27(5):620-8.

38. Kelly JC, Groarke PJ, Butler JS, Poynton AR, O'Byrne JM. The natural history and clinical syndromes of degenerative cervical spondylosis. Adv Orthop. 2012;2012:393642

39. Jimenez-Balderas FJ, Mintz G. Ankylosing spondylitis: clinical course in women and men. J Rheumatol. 1993;20(12):2069-72.

\section{Submit your next manuscript to BioMed Central and we will help you at every step:}

- We accept pre-submission inquiries

- Our selector tool helps you to find the most relevant journal

- We provide round the clock customer support

- Convenient online submission

- Thorough peer review

- Inclusion in PubMed and all major indexing services

- Maximum visibility for your research

Submit your manuscript at www.biomedcentral.com/submit 